\title{
Assessing Institutional Determinants of MP Behaviour: Survey Data from the Baltic States*
}

\author{
VELLO PETTAI** \\ Department of Political Science, University of Tartu
}

\begin{abstract}
To what extent do electoral and legislative institutions affect the behaviour of parliamentarians in new democracies? This article examines this question on the basis of a wide-ranging survey of MPs in the Baltic states from January 2000. Given substantial differences in the types of institutions existing in the three states, the research tests whether these differences are reflected in MPs' responses to key questions about their relationship to and interaction with (1) parliamentary work, (2) their party and faction, (3) individual voters, (4) the interests of their district or constituency, and (5) interest groups. The results corroborate a number of existing theoretical postulates, while leaving unconfirmed others.

Sociologický časopis/Czech Sociological Review 2005, Vol. 41, No. 3: 461-486
\end{abstract}

In the consolidating democracies of Central and Eastern Europe it is a truism that one of the central dimensions of this process is the development of a healthy parliamentary democracy. More specifically, this question concerns the myriad roles parliamentary deputies are expected to fulfil in relation to voters, parties, interest groups, other state institutions, the media, foreign counterparts, etc. In some cases, these roles involve interest mediation, in other cases interest arbitration, and in others oversight and supervision. All of these roles take time to mature, not only onthe part of the MPs, but also in the case of other players. The entire web of relations quickly becomes impossible to grasp all at once. Still, the steady consolidation of democracy in Central and Eastern Europe since the early 1990s has generated clear proof that these relations exist and are to a considerable degree functioning. Although actual popular satisfaction with democracy may vary between countries, the minimum requirements of democratic constitutionalism and respect for fundamental liberties continue to be upheld, not least because of the role(s) played by MPs.

Existing studies on the role of parliamentarians in the new democracies of Cen-

* An initial version of this paper was presented at Workshop no. 16 'A Renewal of Parliaments in Europe? MP's Behaviours and Action Constraints' of the Joint Sessions of the European Consortium for Political Research, 22-27 March 2002, Turin, Italy. The author gratefully acknowledges funding for this work from the Research Support Scheme of the Open Society Support Foundation, grant no. 1700/1999, as well as the Estonian Ministry of Education and Research, Targeted Financing grant no. 0182573.

* Direct all correspondence to: Vello Pettai, Department of Political Science, University of Tartu, Ülikooli 18, 50090 Tartu, Estonia, e-mail: vello.pettai@ut.ee

(C) Sociologický ústav AV ČR, Praha 2005 
tral and Eastern Europe have focused on elite recruitment and circulation [Higley and Lengyel 2000; Higley, Pakulski and Wesolowski 1998; Frantzel-Zagorskia and Wasilewski 2000; Best and Cotta 2002] or on the institutionalisation of parliamentary institutions [Agh and Kurtan 1995] and in particular legislative committees [Olson and Crowther 2002]. These studies have been important either for creating a sociological portrait of the emerging political class in these countries or for examining how politicians come to develop and work within a specific institutional system such as parliamentary committees. Both of these aspects are significant for understanding how democracy works, either in terms of how the professional skills and experiences of actual MPs feed into the political process or how parliamentarians foster a culture of rules and begin to abide by them in order to co-operate and compete peacefully. Yet these studies fall short in two other important dimensions: (1) finding out how MPs actually perceive their own work and (2) exploring the matrix (or crossfire) of influences, which parliamentarians see themselves as having to navigate when doing their job.

This article will examine the state of these MP roles and relationships in three new EU member states: Estonia, Latvia and Lithuania. It will report some of the findings from a survey of MPs in the three countries. The survey, conducted in January 2000, contained over 130 questions relating to a wide range of political behaviours, including MPs' personal political histories, party relations, electoral strategies, parliamentary activities, and role interpretations. The survey represents only a snapshot in time (time series data are as yet unavailable) and the data bear the limitations of any survey of MPs, including the limited sample size, the political sensitivity of certain questions, the particularities of any given parliamentary cohort, environmental influences from exogenous political events, etc. Nevertheless, the data make it possible to establish a baseline of MP behaviour in the Baltic states as an example of the regional development of parliamentary democracy, but also with regard to certain institutional variables, which the Baltic states represent particularly well. With regard to the first goal, I argue that MP behaviour appears to be essentially party-centred in the sense that MPs are bound first and foremost to their party, and less so to voters, interest groups or other political actors. Second, I argue that institutional variables - and in particular electoral institutions - do not appear to have an immediate or unequivocal impact on MP behaviour. For example, more centralised (i.e. party-centred) electoral systems do not appear to promote more centralised political behaviour. On the contrary, in this survey, it was in Latvia, which has the most centralised electoral system, that MPs were the most concerned about addressing constituent and interest group concerns.

The article begins with a short methodological section outlining the parameters of this survey and the essential elements of each country's electoral and political system. This is followed by data on five different role situations that Baltic MPs encounter, i.e. their relationship to and interaction with (1) parliamentary work, (2) their party and faction, (3) individual voters, (4) the interests of their district or constituency, and (5) interest groups. It is not the aim of these sections to provide any extensive interpretation, which is instead contained in the analysis in the final section. 


\section{Methodological and institutional dimensions}

The survey results reported in this paper are part of a broader research project examining the links between political institutions and party cohesion in consolidating democracies. Many of the hypotheses tested in the survey stem from previous work on these institutional frameworks done by Pettai and Kreuzer. ${ }^{1}$ The questionnaire used in the survey was conceived in the tradition of a number of surveys that have been conducted among representatives in the US Congress and MPs in the British House of Commons. In many cases, questions were drawn directly from these surveys in order to facilitate future cross-national comparisons. The survey took place in most cases as an elite interview, although on occasion the parliamentarians preferred to fill out the questionnaires on their own. The fieldwork was carried out in January 2000 by three of the most reputable polling organisations ${ }^{2}$ in the Baltic states, and the survey was coordinated with the help of legislative officials and local scholars in all three countries. ${ }^{3}$

The survey's representative sample was of particular value. In each parliament a minimum $70 \%$ response rate was set as the goal, and in each case this figure was achieved. In addition, the results were commensurate with the parties' strength in parliament (see Table 1). In terms of parliamentary cycles, Estonia's was the youngest group (elected in March 1999), followed by Latvia (October 1998) and Lithuania (October 1996). This factor played out differently in each country, as Estonian deputies were able to answer questions regarding electioneering strategies with the freshest experience, while Lithuanian deputies had the longest time-perspective with regard to legislative activity. Nonetheless, given that in each country a sizeable number of respondents $(44.3 \%)$ were either second- or even third-term parliamentarians, the collective experience of deputies helped to counter some of these cyclical aspects.

One drawback of the survey was the fact that limited financial resources prevented the project from interviewing any politicians other than parliamentary deputies. For questions regarding electoral career control and electioneering, a broader sample of electoral candidates, including those not necessarily elected to parliament, would have been better. ${ }^{4}$ Table 1 shows the relevant data based on the survey's parliamentary sample.

The Baltic states represent an interesting testing ground for patterns of MP behaviour because their electoral and political institutions differ considerably. ${ }^{5} \mathrm{Al}-$

\footnotetext{
${ }^{1}$ See Pettai [2000], Pettai and Kreuzer [1999; 2001], Kreuzer and Pettai [2004].

2 In Estonia, Saar Poll; in Latvia, Baltic Data House; in Lithuania, the Social Information Centre.

${ }^{3}$ Artis Pabriks (Vidzeme University College) and Darious Zeruolis (Vilnius University) served as local liaisons in Latvia and Lithuania, respectively. The author coordinated work in Estonia.

${ }^{4}$ Work in this field regarding Estonian parties has been done by Kangur [2004].

${ }^{5}$ For a more detailed overview of these institutions, see Pettai and Kreuzer [1999], Mikkel and Pettai [2004].
} 
Table 1. Survey sample data, $\mathbf{N}$

\begin{tabular}{lcc}
\hline $\begin{array}{l}\text { Country } \\
\text { Party }\end{array}$ & $\begin{array}{c}\text { Representation in } \\
\text { parliament based on the } \\
\text { most recent election results } \\
\text { prior to the survey }\end{array}$ & $\begin{array}{c}\text { Number of } \\
\text { deputies surveyed }\end{array}$ \\
\hline
\end{tabular}

1. Estonia

Centre Party

$28 \quad 20$

Fatherland Union $\quad 18 \quad 11$

$\begin{array}{lll}\text { Reform Party } & 18 & 11\end{array}$

Moderates 17

10

Coalition Party

$7-5$

People's Union

$\begin{array}{ll}7 & 7\end{array}$

United People's Party

$8-6$

Not given

11
11
10
5
7
6
1

TOTAL

101

71

2. Latvia

People's Party

Latvia's Way*

Fatherland and Freedom

17

Harmony Party

Socialist Party

Equal Rights Party

16

Russian Party

Social Democrats

14

New Party

TOTAL

100

\section{Lithuania}

Homeland Union

Christian Democratic Party

Centre Union

Democratic Labour Party

Social Democrats

Union of Poles

Others

* Includes one deputy who gave party affiliation as 'LW Ally'.

** Includes deputies who have broken away from their original parties since the 1996 election. 
though all three countries regained their independence simultaneously from the Soviet Union in 1991 and all three shared the legacy of fifty years of Soviet rule, they each went on to adopt radically different institutional frameworks, which as a result provide a unique opportunity to study the effects of different institutions on political behaviour under relatively similar economic and social conditions. For example, Estonia has a relatively personalised PR electoral system, in which candidates run as individuals and can be elected directly from their district if they fulfil a minimum (Hare) vote quota. However, at the same time all candidates are also on a national list, which is used to allocate all remaining seats that are not won immediately at the district level. ${ }^{6}$ Generally in Estonian elections, roughly half of the mandates are accorded at the district level, the other half at the national list level. As a result, Estonian politicians play a dual game, running in their districts as individual candidates, while at the national level they are bound to their ranking on the party list. ${ }^{7}$ Constitutionally, Estonia has a parliamentary form of government. Although the system also includes a president, the office is largely ceremonial and the president is elected either by parliament or by an electoral college, not by popular vote.

Latvia's constitutional structure echoes Estonia's in that it, too, has a parliamentary form of government with a weak president chosen by parliament. At the same time, Latvia's electoral system is strictly PR, based on party lists nominated in each of the country's five electoral districts. As a result candidates are much more closely linked to their party's fortunes. Nevertheless, an element of uncertainty (or candidate opportunity) also exists, to the extent that Latvian voters are allowed a preference vote within the party list that they choose. Beside each candidate's name, voters can place either a ' + ' or ' - ' sign or leave it blank. In turn, any mandates that the list receives in the district are awarded to individual candidates based on their respective preference score. As a consequence, candidates have an opportunity for personalistic campaigning by encouraging voters to approbate their own names, while striking out fellow candidates on the party list. (Anecdotal evidence suggests that this is a broad occurrence.)

Lithuania's electoral system is one of the few hybrid systems in the world. ${ }^{8}$ Of the Seimas's 141 members 70 are elected through a single, nationwide multi-member district (MMD) based on party lists and proportional representation with a 5\% voting threshold. The remaining seats are elected via 71 single-member districts (SMDs) based on two rounds of voting. ${ }^{9}$ This creates another dual dynamic within the political system, given that, although candidates can run on both levels, single-

\footnotetext{
${ }^{6}$ A minimum 5\% vote threshold also exists for parties to be eligible for seats at this third, national level of seat allocation.

7 This would seem to make Estonia almost a mixed electoral system, but it is not, as voters only cast one ballot for an individual candidate at the district level. The catch is that these single votes are simply amalgamated differently at each respective level of mandate distribution.

8 That said, the number of such systems is growing. See Shugart and Wattenberg [2001].

9 For the October 2000 elections, the two-round system was dropped and a single-round 'first-past-the-post' system was adopted. In 2004, the two-round system was restored.
} 
Table 2. 'When parliament is in session, how time-consuming would you rate the following activities?' Mean, (SD)

\begin{tabular}{|c|c|c|c|c|}
\hline & Estonia & Latvia & Lithuania & Baltic average \\
\hline \multicolumn{5}{|l|}{ 1. Parliamentary activities } \\
\hline \multirow[t]{2}{*}{ a) attending parliamentary debates } & 1.7647 & 1.9155 & 1.9907 & 1.9069 \\
\hline & $(.5496)$ & $(.7699)$ & $(.7298)$ & (.7009) \\
\hline \multirow[t]{2}{*}{$\begin{array}{l}\text { b) working in standing parliamentary } \\
\text { committees }\end{array}$} & 1.6901 & 1.5352 & 1.4685 & 1.5494 \\
\hline & $(.5755)$ & $(.5300)$ & $(.5692)$ & $(.5657)$ \\
\hline \multirow{3}{*}{$\begin{array}{l}\text { c) government oversight (preparing } \\
\text { for question-time, investigative } \\
\text { committees) }\end{array}$} & & & & \\
\hline & 2.6522 & 2.6197 & 2.2909 & 2.4840 \\
\hline & $(.6603)$ & $(.8513)$ & $(.7083)$ & $(.7563)$ \\
\hline \multirow[t]{2}{*}{ d) meeting informally with other MPs } & 2.8169 & 2.2535 & 2.6415 & 2.5806 \\
\hline & $(.5427)$ & $(.7313)$ & $(.6353)$ & $(.6745)$ \\
\hline \multicolumn{5}{|l|}{ 2. Party activities } \\
\hline \multirow[t]{2}{*}{$\begin{array}{l}\text { a) attending party meetings } \\
\text { (e.g. faction, national board) }\end{array}$} & 2.3662 & 2.2254 & 2.3458 & 2.3173 \\
\hline & $(.5914)$ & $(.7010)$ & $(.7282)$ & $(.6837)$ \\
\hline \multirow[t]{2}{*}{ b) attending local party meetings } & 2.8286 & 2.4000 & 2.3178 & 2.4858 \\
\hline & $(.7014)$ & $(.6895)$ & $(.6530)$ & $(.7091)$ \\
\hline \multicolumn{5}{|l|}{ 3. Voter concerns } \\
\hline \multirow{2}{*}{$\begin{array}{l}\text { a) helping local voters solve personal } \\
\text { problems in dealing with } \\
\text { the government }\end{array}$} & 2.4648 & 2.2958 & 1.7838 & 2.1186 \\
\hline & $(.7138)$ & $(.7444)$ & $(.6523)$ & $(.7571)$ \\
\hline \multicolumn{5}{|l|}{ 4. District activities } \\
\hline \multirow[t]{2}{*}{ a) holding constituency meetings } & 2.7571 & 2.2113 & 1.8649 & 2.2103 \\
\hline & $(.7506)$ & $(.5585)$ & $(.6535)$ & $(.7518)$ \\
\hline \multicolumn{5}{|l|}{ 5. Interest groups } \\
\hline \multirow[t]{2}{*}{ a) meeting with interest groups } & 2.7571 & 2.2676 & 2.5701 & 2.5363 \\
\hline & $(.7310)$ & $(.6752)$ & $(.7538)$ & $(.7466)$ \\
\hline
\end{tabular}

$1=$ Very time-consuming, $4=$ No attention required.

member district campaigning tends to be much more personalistic. ${ }^{10}$ In addition, once elected to parliament, party groups may be split between SMD and MMD deputies, as their electoral interests may not always coincide. Finally, Lithuania's constitutional system is semi-presidential, wherein a popularly elected president

${ }^{10}$ For a comparison of these different effects, see Moser [2004]. 
shares power with a parliament-appointed prime minister. Although the presidential and parliamentary elections are not concurrent, their dual existence adds yet another dimension to party politics.

In each of these three institutional profiles, it is possible to see cross-cutting institutional effects, which means that, on the whole, none of the countries represents an unambiguous type of institutional constellation. In terms of case selection and research design, this would seem to pose a problem given the apparent impossibility of clearly ranking the institutions in the three countries (as the independent variable) in order to juxtapose them with the survey results (the dependent variable). Nevertheless, the countries are very different in their institutional make-up and I would argue that some of the countervailing aspects of one or another system are not significant enough to override the general trend. In this respect, Lithuania could be best classified as the most personalistic electoral system (because of its SMD voting), Estonia semi-personalistic (because of its mix of district candidacies, but also national-level party lists where roughly half of all deputies have gained their seats) and Latvia least personalistic (because of its primary focus on party lists, wherein preference votes come into play only secondarily). ${ }^{11}$ Certainly other research designs are possible; however, the lack of readily available data precludes making any such study for the time being.

Table 2 provides a general overview of how Baltic MPs assessed the structure of their activities as parliamentarians across different parliamentary roles. In response to the question "When parliament is in session, how time consuming would you rate the following activities?", deputies were given a list of nine activities, which were all related to work as an MP. The respondents' answers were based on a four-point scale, where 1 equals 'very time-consuming' and 4 equals 'no attention required at all'. ${ }^{12}$

As one might imagine, parliamentary activities took up the most time among Baltic MPs, and in particular work in parliamentary committees. General oversight was a less demanding parliamentary role, although in Lithuania (where a large number of investigative committees were created during the 1990s) this figure was relatively high, indeed surpassing that of party activities. Next among general categories was that of dealing directly with the personal problems of voters and with electoral constituencies as a whole. It is worth making a distinction between these two parliamentary roles since the first concerns engaging individually with citizens, while the second relates to monitoring the interests of an entire electoral district. In both of these areas, Lithuanian deputies were again ahead of their Baltic counterparts, and with respect to constituency care they outstripped Estonian MPs by al-

\footnotetext{
11 These characterisations are based on a number of classic works on electoral systems, including Grofman and Lijphart [1986], Katz [1980], Lijphart [1994], LeDuc, Niemi and Norris [1996], and Cox [1997].

12 All of the scale questions in the survey were structured so that 1 equaled the highest and 4 equaled the lowest. Therefore, for all these questions, the lower the mean is, the higher the respondent's agreement with the statement or degree of involvement in the given question category.
} 
most a full point on the four-point scale. Thirdly, party activities also accounted for a significant share of MPs' time. This category includes attending both parliamentary caucus meetings as well as in many cases other party meetings. For example, a full $75.7 \%$ of the survey respondents reported also having held, at least once before, a formal position in their party (either at the national or the local level). Baltic deputies showed the least interest in interest groups, stating $40 \%$ of the time that dealing with these groups was not very time consuming. Nevertheless, this category ranked considerably higher among Latvian deputies.

\section{Parliamentary activities}

As noted above, MPs often stand at the nexus of a number of cross-cutting influences and intersecting levels of political power. One such competing level is involvement in local politics or civic organisations. In all three Baltic states parliamentary deputies are allowed to simultaneously hold office at both the national and the local legislative level. This French-style cumul de mandats means not only extra work, but often also conflicting party-political interests, when local coalitions differ from national ones. Estonia offers a particularly recent example, where an abrupt shift in the coalition governing the capital Tallinn in December 2001 eventually led to a collapse of the national government in favour of a similarly fashioned alternative coalition. The original centre-right coalition in Tallinn, involving mainly the nationalist Pro Patria Union, the liberal Reform Party and the centrist Moderates, broke up in December 2001, when the Reform Party decided to form a new majority with the leftish Centre Party. This sudden switch prompted the Pro Patria Union and the Moderates to review the three-party coalition at the national level, and eventually Prime Minister Mart Laar (from the Pro Patria Union) decided to resign in protest over the Reform Party's behaviour. The Reform Party then went on to form a national government with the Centre Party, thus completing the local-gone-national bouleversement. A major reason given by commentators for the political chain reaction (or short-circuit) was the fact that many members of the Tallinn City Council were also national MPs. As a result, once the capital's legislature suffered a collapse of confidence among its leading members, these strains had to reverberate at the national level too.

Within the framework of this research, it has not as yet been possible to compile precise data on the level of local office-holding among Baltic deputies. Nevertheless, as part of an attempt to build a sociological profile of Baltic deputies, the survey did include questions on whether MPs had previously held local office and to what extent they were also members of civic organisations.

In this regard it was apparent that Estonian deputies had much stronger links to local politics than their Latvian and Lithuanian colleagues. Nearly three-quarters of Estonian parliamentarians had had some level of local political experience. The involvement of deputies in civic organisations was similarly quite widespread. Of 
Table 3. 'Have you ever also held local office?' (\%)

\begin{tabular}{lcccc}
\hline & Estonia & Latvia & Lithuania & Baltic average \\
\hline $\begin{array}{l}\text { 1. Yes } \\
\text { 2. If yes, please indicate the type }\end{array}$ & 74.6 & 46.5 & 50.4 & 56.1 \\
of post: & & & & \\
a) Local council member & 96.2 & 78.8 & 78.8 & 85.4 \\
b) Mayor & 0 & 9.1 & 17.3 & 8.8 \\
c) Other & 3.8 & 12.1 & 3.8 & 5.8 \\
\hline
\end{tabular}

Table 4. 'Have you ever been a member of a professional association, labour union, church organisation or other group?' (\%)

\begin{tabular}{lcccc}
\hline & Estonia & Latvia & Lithuania & Baltic average \\
\hline $\begin{array}{l}\text { 1. Yes } \\
\begin{array}{l}\text { 2. If yes, did you at any time hold } \\
\text { a formal position in that } \\
\text { organisation? }\end{array}\end{array}$ & 69.0 & 77.5 & 73.5 & 73.3 \\
\begin{tabular}{l} 
a) Yes \\
\hline
\end{tabular} & 63.3 & 78.2 & 70.2 & 70.7 \\
\hline
\end{tabular}

course, both of these factors were compounded by the fact that the three Baltic states are very small: together they total just 7.5 million people; roughly 1.4 million in Estonia, 2.4 million in Latvia and 3.5 million in Lithuania. Therefore, their politicians are likely to be active in numerous different ways given that the countries' elite bases are also small. Nevertheless, to the extent that such sociological givens were compounded by other political rules (such as dual office-holding), it is possible to clearly identify areas where institutional engineering was a factor in broader political processes.

\section{Party pressures ${ }^{13}$}

As legislators, MPs must operate within the political scope of their party faction while also adhering more broadly to the positions of their national party hierarchy. In most cases, MPs are therefore bound to the party in a number of ways, starting with electoral nomination, but also including committee appointments in parliament and factional membership where conflicts arise. This section presents an assessment of the roles of MPs based on answers to different survey questions. ${ }^{14}$

\footnotetext{
13 This section draws on Pettai et. al. [2000].

${ }_{14}$ Again, from a methodological point of view it is impossible to fully assess candidate recruitment and selection patterns based on a survey sample of MPs, as the data are skewed to
} 
The career of an MP invariably begins with his/her initial foray into the electoral competition. However, this process involves two important intermediary stages, both of which are influenced centrally by constraints set by the MPs' political party. MPs must first be recruited, and then suitably ranked on a party's electoral list in order to sustain a legislative career from term to term. In the survey we queried deputies about their particular experiences in this regard. In addition, in order to see who has control over an MP's appointment and removal from parliamentary committees this section also examines the legislative level. Here again the party may establish constraints on an MP's career and therefore influence his/her behaviour.

Governance arrangements regulating electoral and legislative careers fall roughly into three categories. They can either be:

- autocratic, by concentrating decision-making in the hands of national leaders,

- democratic, by devolving the decisions to formal, democratically constituted party organs, or

- pluralistic, if decisions result from an informal bargaining process among different constituent groups within a party.

As the following analysis shows, most Baltic deputies must reckon with party structures that can readily be described as autocratic. At the same time, exceptions exist in each Baltic country; thus autocratic party governance does not seem to be an inevitable constraint for MPs in consolidating democracies.

Tables 5 to 7 summarise the different electoral control patterns as described by our parliamentarian respondents. To simplify the analysis somewhat, the three governance categories are further delineated based on the spread of their means. In autocratic parties, national leaders dominate both the recruitment and the ranking of candidates. Moreover, the margin by which respondents judge the influence of national leaders to be greater than that of party conferences or local leaders must be at least 0.3 points greater. In pluralistic parties, national leaders either do not exert simultaneous control over recruitment and ranking or they do so by a very small margin $(<0.3)$. In such parties, the fate of electoral career changes is determined through bargaining among national leaders, local party officials, and the party congress. Finally, in democratic parties, party conferences will be more important than national or local leaders in determining both electoral career stages.

The tables show that in most instances Baltic party leaders exert a disproportionate influence over both the recruitment and ranking of MPs as candidates. ${ }^{15}$ Party congresses also have marginally more control than local party leaders especially when it comes to ranking. However, these general features also vary some-

the extent that they only include winners at the polls. Any such study would require a broader sample including all candidates for election. In this instance, however, the survey data are presented in order to describe the situation of those candidates who made it into parliament and how this background experience may influence their subsequent behavior as MPs.

15 This agrees with other research done in Estonia by Kangur [2004]. 
Table 5. Electoral career governance in Estonia, Mean (N)

\begin{tabular}{|c|c|c|c|}
\hline \multirow{2}{*}{$\begin{array}{l}\text { Governance type } \\
\text { Party }\end{array}$} & \multicolumn{3}{|c|}{ Recruitment controlled by... } \\
\hline & $\begin{array}{c}\text {... national } \\
\text { leaders }\end{array}$ & $\begin{array}{l}\text {.. party } \\
\text { conference }\end{array}$ & ... local \\
\hline \multicolumn{4}{|l|}{ 1. Autocratic } \\
\hline Coalition Party & $1.5(4)$ & $3.5(4)$ & $1.8(4)$ \\
\hline United People's Party & $1.6(5)$ & $2.3(6)$ & $2.8(5)$ \\
\hline Moderates & $1.5(8)$ & $2.0(7)$ & $2.4(7)$ \\
\hline Reform Party & $2.0(11)$ & $2.6(9)$ & $2.5(11)$ \\
\hline Sub-average $(43.8 \%)$ & 1.7 & 2.5 & 2.4 \\
\hline \multicolumn{4}{|l|}{ 2. Pluralistic } \\
\hline Centre Party & $2.1(20)$ & $2.3(18)$ & $2.3(19)$ \\
\hline Sub-average (31.3\%) & 2.1 & 2.3 & 2.3 \\
\hline \multicolumn{4}{|l|}{ 3. Democratic } \\
\hline Fatherland Union & $2.0(11)$ & $1.9(11)$ & $2.1(11)$ \\
\hline People's Union & $2.0(5)$ & $1.5(6)$ & $2.0(6)$ \\
\hline Sub-average (25\%) & 2.0 & 1.8 & 2.1 \\
\hline Total: & $1.9(64)$ & $2.2(61)$ & $2.3(63)$ \\
\hline
\end{tabular}

\begin{tabular}{|c|c|c|c|}
\hline \multirow{2}{*}{$\begin{array}{l}\text { Governance type } \\
\text { Party }\end{array}$} & \multicolumn{3}{|c|}{ Ranking controlled by... } \\
\hline & $\begin{array}{c}\ldots . \text { national } \\
\text { leaders }\end{array}$ & $\begin{array}{l}\text {... party } \\
\text { conference }\end{array}$ & ... local \\
\hline \multicolumn{4}{|l|}{ 1. Autocratic } \\
\hline Coalition Party & $1.3(4)$ & $3.0(4)$ & $2.5(4)$ \\
\hline United People's Party & $1.2(5)$ & $2.7(6)$ & $2.8(5)$ \\
\hline Moderates & $1.5(8)$ & $2.0(6)$ & $2.8(5)$ \\
\hline Reform Party & $1.7(11)$ & $3.0(10)$ & $2.5(11)$ \\
\hline Sub-average (43.8\%) & 1.5 & 2.7 & 2.6 \\
\hline \multicolumn{4}{|l|}{ 2. Pluralistic } \\
\hline Centre Party & $1.7(18)$ & $2.2(19)$ & $2.2(20)$ \\
\hline Sub-average (31.3\%) & 1.7 & 2.2 & 2.2 \\
\hline \multicolumn{4}{|l|}{ 3. Democratic } \\
\hline Fatherland Union & $1.5(11)$ & $1.5(11)$ & $2.5(11)$ \\
\hline People's Union & $2.0(5)$ & $1.7(6)$ & $2.0(6)$ \\
\hline Sub-average (25\%) & 1.7 & 1.5 & 2.4 \\
\hline Total: & $1.6(62)$ & $2.1(62)$ & $2.4(62)$ \\
\hline
\end{tabular}

Note: 1 = Full control, 4 = No control. 
Table 6. Electoral career governance in Latvia, Mean (N)

\begin{tabular}{|c|c|c|c|}
\hline \multirow{2}{*}{$\begin{array}{l}\text { Governance type } \\
\text { Party }\end{array}$} & \multicolumn{3}{|c|}{ Recruitment controlled by... } \\
\hline & $\begin{array}{c}\ldots . \\
\text { leadional } \\
\text { leadional }\end{array}$ & $\begin{array}{l}\text {... party } \\
\text { conference }\end{array}$ & $\begin{array}{c}\ldots \text { local } \\
\text { leaders }\end{array}$ \\
\hline \multicolumn{4}{|l|}{ 1. Autocratic } \\
\hline Socialist Party & $1.3(4)$ & $2.8(4)$ & $1.8(4)$ \\
\hline People's Party & $1.9(17)$ & $2.6(18)$ & $2.5(17)$ \\
\hline Equal Rights & $1.0(4)$ & $3.0(4)$ & $2.3(4)$ \\
\hline Social Democrats & $2.1(13)$ & $2.6(13)$ & $2.5(13)$ \\
\hline Sub-average (54.3\%) & 1.8 & 2.7 & 2.4 \\
\hline \multicolumn{4}{|l|}{ 2. Pluralistic } \\
\hline Latvia's Way & $1.9(10)$ & $2.0(10)$ & $2.2(10)$ \\
\hline Harmony Party & $2.3(3)$ & $2.3(3)$ & $3.7(3)$ \\
\hline New Party & $2.3(3)$ & $2.3(3)$ & $2.7(3)$ \\
\hline Sub-average $(25.7 \%)$ & 2.1 & 2.3 & 2.5 \\
\hline \multicolumn{4}{|l|}{ 3. Democratic (20\%) } \\
\hline Fatherland and Freedom & $2.3(14)$ & $2.1(14)$ & $2.7(14)$ \\
\hline Total & $2.0(70)$ & $2.5(71)$ & $2.5(70)$ \\
\hline
\end{tabular}

\begin{tabular}{|c|c|c|}
\hline \multirow{2}{*}{$\begin{array}{l}\text { Governance type } \\
\text { Party }\end{array}$} & \multicolumn{2}{|c|}{ Ranking controlled by... } \\
\hline & $\begin{array}{c}\ldots . \text { national } \\
\text { leaders }\end{array}$ & $\begin{array}{ll}\ldots \text { party } & \ldots \text { local } \\
\text { conference } & \text { leaders }\end{array}$ \\
\hline
\end{tabular}

1. Autocratic

$\begin{array}{llll}\text { Socialist Party } & 1.3(4) & 3.5(4) & 3.8(4) \\ \text { People's Party } & 1.9(16) & 3.6(17) & 2.9(17) \\ \text { Equal Rights } & 1.3(4) & 3.3(4) & 1.8(4) \\ \text { Social Democrats } & 2.5(13) & 3.0(12) & 2.6(13) \\ \text { Sub-average }(54.3 \%) & 1.9 & 3.4 & 2.8\end{array}$

\section{Pluralistic}

$\begin{array}{llll}\text { Latvia's Way } & 2.1(10) & 2.9(10) & 2.4(10) \\ \text { Harmony Party } & 2.3(3) & 3.7(3) & 3.0(3) \\ \text { New Party } & 2.0(3) & 2.7(3) & 2.3(3) \\ \text { Sub-average }(25.7 \%) & 2.2 & 3.1 & 2.6\end{array}$

3. Democratic (20\%)

$\begin{array}{llll}\text { Fatherland and Freedom } & 2.7(14) & 2.6(14) & 3.0(14) \\ \text { Total } & \mathbf{2 . 2 ( 6 9 )} & \mathbf{3 . 1}(\mathbf{6 9 )} & \mathbf{2 . 8 ( 7 0 )}\end{array}$

Note: Only parties with at least 3 respondents shown. Sub-averages, however, include all respondents. 1 = Full control, $4=$ No control. 
Table 7. Electoral career governance in Lithuania, Mean (N)

\begin{tabular}{|c|c|c|c|}
\hline \multirow{2}{*}{$\begin{array}{l}\text { Governance type } \\
\text { Party }\end{array}$} & \multicolumn{3}{|c|}{ Recruitment controlled by... } \\
\hline & $\begin{array}{c}\text {... national } \\
\text { leaders }\end{array}$ & $\begin{array}{l}\text {.. party } \\
\text { conference }\end{array}$ & ... local \\
\hline \multicolumn{4}{|l|}{ 1. Autocratic } \\
\hline Homeland Union & $1.7(51)$ & $2.8(45)$ & $2.4(46)$ \\
\hline Centre Union & $1.7(13)$ & $2.8(13)$ & $2.5(13)$ \\
\hline Sub-average $(61.3 \%)$ & 1.7 & 2.8 & 2.4 \\
\hline \multicolumn{4}{|l|}{ 2. Pluralistic } \\
\hline Social Democrats & $2.3(7)$ & $2.9(7)$ & $2.6(7)$ \\
\hline Dem. Labour Party & $1.8(11)$ & $2.1(11)$ & $2.2(11)$ \\
\hline Sub-average (18.9\%) & 2.0 & 2.4 & 2.3 \\
\hline \multicolumn{4}{|l|}{ 3. Democratic } \\
\hline Christian Dem. Party & $2.1(11)$ & $2.1(10)$ & $2.6(11)$ \\
\hline Sub-average (19.8\%) & 2.1 & 2.1 & 2.4 \\
\hline Total: & $1.9(106)$ & $2.4(99)$ & $2.3(101)$ \\
\hline
\end{tabular}

\begin{tabular}{|c|c|c|c|}
\hline \multirow{2}{*}{$\begin{array}{l}\text { Governance type } \\
\text { Party }\end{array}$} & \multicolumn{3}{|c|}{ Ranking controlled by... } \\
\hline & $\begin{array}{c}\text {... national } \\
\text { leaders }\end{array}$ & $\begin{array}{l}\text {... party } \\
\text { conference }\end{array}$ & ... local \\
\hline \multicolumn{4}{|l|}{ 1. Autocratic } \\
\hline Homeland Union & $1.4(51)$ & $2.9(46)$ & $2.9(46)$ \\
\hline Centre Union & $1.3(12)$ & $2.8(12)$ & $2.3(12)$ \\
\hline Sub-average $(61.3 \%)$ & 1.4 & 2.9 & 2.7 \\
\hline \multicolumn{4}{|l|}{ 2. Pluralistic } \\
\hline Social Democrats & $2.6(7)$ & $2.1(7)$ & $2.7(7)$ \\
\hline Dem. Labour Party & $1.9(10)$ & $1.9(10)$ & $2.6(10)$ \\
\hline Sub-average (18.9\%) & 2.1 & 2.0 & 2.6 \\
\hline \multicolumn{4}{|l|}{ 3. Democratic } \\
\hline Christian Dem. Party & $1.9(10)$ & $1.9(10)$ & $2.9(10)$ \\
\hline Sub-average (19.8\%) & 1.9 & 1.7 & 2.8 \\
\hline Total: & $1.8(102)$ & $2.2(98)$ & $2.7(97)$ \\
\hline
\end{tabular}

Note: Only parties with at least 4 respondents shown. Sub-averages, however, include all respondents. 1 = Full control, $4=$ No control. 
what between the three countries. For instance, Lithuania could be characterised as the most autocratic party system, with $61.3 \%$ of respondents belonging to autocratic parties, compared to $54.3 \%$ in Latvia and $43.8 \%$ in Estonia. Lithuania also has the smallest percentage of respondents $(19.8 \%)$ who belong to democratic parties, compared to $25.7 \%$ in Latvia and $25 \%$ in Estonia. Nonetheless, these national figures must be disaggregated, as they conceal what are in reality important cross-party differences. For instance, it is perhaps somewhat surprising that the Democratic Labour Party (LDLP) or the communist successor party belong to the pluralistic category in Lithuania. Especially when compared to Latvia's successor parties (the Socialist Party and Equal Rights), the LDLP seems to have been quite successful in shedding any Leninist legacies inherited from Soviet times. Similarly counterintuitive is the inclusion of Estonia's Centre Party in the pluralistic camp, as its leader, Edgar Savisaar, is widely considered to be relatively autocratic. ${ }^{16}$ Nonetheless, according to the party's 20 respondents, control over electoral careers is fairly evenly distributed among its different constituent groups. This may be a reflection of the fact that the party is also one of Estonia's largest (with roughly 7600 members), which may mean that broadly based participation (or at least a sense of such participation) is more likely. It is interesting to note also that in Latvia the strongly nationalist Fatherland and Freedom Party ultimately constitutes the country's only 'democratic' party. Here one explanation may be that the party began as a coalition of nationalist groups in 1993 and may have retained a consensual style of decision-making ever since. Finally, one important fact that is not reported in the tables is the marginal influence that interest groups have on electoral careers in all three countries. Respondents generally rated the influence of interest groups on recruitment and ranking somewhere between 'weak control' and 'no control'. Therefore, political parties in the Baltics do not appear to be vehicles for special interest groups. Whether this is to be taken as an indicator of the strength of party autonomy, or of the underdevelopment of interest groups, or both, is a question that must be studied further.

MPs' careers (and the constraints upon them) extend well beyond a successful electoral candidacy. In the legislative arena, committee appointments, promotions to legislative executive office and even selection to cabinet posts provide important advancement opportunities. Control over these opportunities therefore constitutes another key determinant in the behaviour of MPs. At the same time, electoral and legislative behavioural constraints differ in a number of respects. First, the actors in the legislative arena differ from those at the electoral career stage. Decisions about legislative careers are usually brokered between party leaders, faction chairs, and regular faction members. Local party leaders or party conferences rarely if ever are involved at this career stage. Second, legislative career control does not offer quite the same leverage as control over electoral careers because it involves making decisions about career advances rather than deciding whether or not a party member will

${ }_{16}$ Indeed, in 2004 a major rift in the party opened up when a total of eight MPs split from the party's faction in the Riigikogu, complaining specifically about Savisaar's leadership style. 
Table 8. 'Based on your experience, please assess the influence that the following groups/individuals had on your committee appointment?' Mean, (SD)

\begin{tabular}{lcccc}
\hline & Estonia & Latvia & Lithuania & Baltic average \\
\hline 1. Faction & 2.25 & 2.20 & 2.36 & 2.28 \\
& $(0.77)$ & $(0.92)$ & $(0.93)$ & $(0.89)$ \\
2. Party board & 2.58 & 2.76 & 2.87 & 2.76 \\
& $(0.91)$ & $(0.98)$ & $(1.02)$ & $(0.98)$ \\
3. Faction chair & 2.40 & 2.07 & 2.65 & 2.43 \\
& $(0.76)$ & $(0.83)$ & $(0.84)$ & $(0.85)$ \\
4. Personal preference & 1.86 & 1.54 & 1.95 & 1.81 \\
& $(0.77)$ & $(0.77)$ & $(0.76)$ & $(0.78)$ \\
\hline
\end{tabular}

Note: 1 = Full control, 4 = No control.

actually have a career. Legislative career control thus constitutes a secondary, complementary type of leverage. Nevertheless, it is worthwhile examining, as it introduces an important additional facet of MP behaviour. Depending on given patterns of legislative career control we can draw inferences about whether the faction chair, the party board, or the faction itself controls committee appointments. In the survey deputies were asked to assess the influence that different actors (including themselves) have on their final committee appointment in parliament and express their answer on the same four-point scale used in the previous question (ranging from 1, 'full control', to 4, 'no control').

As Table 8 reveals, the legislative career patterns in all three countries differ notably from their electoral counterparts. First, a horizontal look at the rows shows few country-specific legislative control patterns, since faction chairs, party boards and factions themselves exert more or less the same level of influence in each country. Similarly, a vertical glance at the country columns reveals a fairly undifferentiated picture. For example, party boards are not surprisingly rated as having the least influence. In this respect, the Baltic countries differ little from most other democracies in which extra-parliamentary party organs usually have little control over legislative careers. However, what is surprising is the small difference between factions and faction chairs. Typically, one of the two has more control over committee appointments than the other. For Estonia, Latvia, and Lithuania, however, the two are rated as having virtually the same level of influence. Moreover, since the standard deviation for each individual party (not reported in this table) is very small, we can guess that this is perhaps even an institutional phenomenon.

The absence of any legislative control pattern is evident from the last row in Table 8 and from Table 9 . In Table 8 we can see that ultimately the personal preference of deputies constituted the most important factor in determining committee appointments among the survey respondents. Legislative career choices would thus 
Table 9. 'If on a frequent basis or on a crucial plenary or committee vote you were to defy your party's voting instructions, what would be the most likely sanction you would face? [Please tick all appropriate responses.]' (\%) (N)

\begin{tabular}{lccc}
\hline & Estonia & Latvia & Lithuania \\
\hline a) Expulsion & $0(0)$ & $6(4)$ & $14.8(16)$ \\
b) No re-nomination & $14.9(10)$ & $6(4)$ & $3.7(4)$ \\
c) No promotion & $3.0(2)$ & $9.0(6)$ & $26.9(29)$ \\
d) Committee removal & $1.5(1)$ & $0(0)$ & $5.6(6)$ \\
e) Warning & $62.7(45)$ & $64.2(43)$ & $42.6(46)$ \\
f) Nothing & $37.3(25)$ & $22.4(15)$ & $39.8(43)$ \\
\hline
\end{tabular}

appear to be somewhat self-selective. Table 9 shows that when deputies were asked what would happen if they consistently voted against their faction's political position, an overwhelming majority of respondents in all three countries replied that (at least at the time of this survey) they would face only minor sanctions, if anything at all. This is on top of the fact that deputies had more than one option to choose from. Given that in most democracies defiance of party leaders in legislative votes is considered a serious offence and is likely to jeopardise a deputy's career prospects this finding is significant [Bowler, Farrel and Katz 1999]. Nevertheless, the most commonly reported sanction in the survey was a warning or a slap on the wrist. Only in Lithuania did deputies rate the likelihood of expulsion or a denial of promotions as significant; and in this particular case a cross-tabulation by party showed that many of these deputies were from the Homeland Union, which probably reflected the fact that HU deputies (Laima Andrikiene and Vidmantas Ziemelis) had been expelled from the party in 1999.

\section{Voter assistance}

Central to the efficacy of parliamentary government is not only the democratic election of legislators, but also the responsiveness of these legislators to citizen inputs and demands. Such links between MPs and their direct constituents have been extensively studied in Western democracies [Cain, Ferejohn and Fiorina, 1987], but much less so in Central and Eastern European countries. In the given survey, five questions were particularly designed to assess the degree to which Baltic deputies come into regular contact with their voters and how much they pursue efforts to directly assist such citizens. Beginning with a simple question about how often MPs are asked to intervene on behalf of a constituent in some personal government manner (Table 10), it is readily apparent that deputy-voter relations are strongest in Lithuania.

Not only do Lithuanian deputies seem to be comparatively inundated with voter requests, but they also appear in many cases to have factored this into their fu- 
Table 10. 'In an average month, how often are you asked by a district voter to intervene on his or her behalf in a governmental agency?' (\%)

\begin{tabular}{lcccc}
\hline & Estonia & Latvia & Lithuania & Baltic average \\
\hline a) Rarely & 38.0 & 16.9 & 4.4 & 17.3 \\
b) 1-4 times & 46.5 & 49.3 & 24.8 & 37.6 \\
c) 5-10 times & 14.1 & 16.9 & 21.2 & 18.0 \\
d) 10+ times & 4.5 & 16.9 & 49.6 & 27.1 \\
\hline
\end{tabular}

Table 11. 'If you provide individual voters with bureaucratic assistance, do you intend to remind them at election time of your help?' (\%)

\begin{tabular}{lcccc}
\hline & Estonia & Latvia & Lithuania & Baltic average \\
\hline a) Yes & 9.9 & 14.9 & 32.7 & 21.1 \\
b) No & 90.1 & 85.1 & 68.3 & 78.9 \\
\hline
\end{tabular}

Table 12. 'Could you tell us whether you agree or disagree with the following statements about the work of members of parliament?' Mean, (SD)

\begin{tabular}{lcccc}
\hline & Estonia & Latvia & Lithuania & Baltic average \\
\hline $\begin{array}{l}\text { a) Solving voters' problems is one } \\
\text { of the most worthwhile parts } \\
\text { of my job. }\end{array}$ & 2.35 & 2.00 & 2.20 & 2.18 \\
& $(0.60)$ & $(0.70)$ & $(0.73)$ & $(0.70)$ \\
$\begin{array}{l}\text { b) An MP who actively looks after } \\
\text { voter interests can increase his/her } \\
\text { chances of being re-elected. }\end{array}$ & 2.02 & 1.66 & 1.87 & 1.85 \\
& $(0.57)$ & $(0.48)$ & $(0.64)$ & $(0.59)$ \\
$\begin{array}{l}\text { c) Members spend too much time } \\
\text { looking after the interests of their } \\
\text { voters, thereby neglecting national } \\
\text { interests or problems. }\end{array}$ & 3.00 & 2.91 & 2.71 & 2.85 \\
& $(0.59)$ & $(0.72)$ & $(0.72)$ & $(0.69)$ \\
$\begin{array}{l}\text { d) MPs are elected to serve national } \\
\text { interest rather than to resolve } \\
\text { voters' problems. }\end{array}$ & 1.99 & 2.33 & 2.40 & 2.25 \\
& $(0.83)$ & $(0.93)$ & $(0.77)$ & $(0.83)$ \\
\hline
\end{tabular}

$1=$ Strongly agree, $4=$ Strongly disagree . 
ture electoral strategy. At the same time, when asked how often they act on a voter request, an average of $56 \%$ of all Baltic deputies answered 'always' and $40 \%$ 'sometimes'.

In this respect, it is worth looking at the same issue in a more direct manner. In the survey, Baltic MPs were asked to express their opinion regarding four interrelated statements about the need to deal with voter problems. As Table 12 shows, it is to be expected that the first two statements exhibit lower means in order to reflect the agreement with the statement $(1=$ fully agree). The other two statements represent the converse attitude, signifying a higher mean. The results again show Lithuanian deputies are slightly more inclined to pay attention to voter affairs, although Latvian MPs also demonstrate a ready belief in the merits of such action (Row b).

\section{District interests}

Although MPs may often be careful to address the constituent concerns that reach them directly, a more effective way of winning votes comes from assisting an entire district or region. In this regard the survey asked to what extent MPs strive to provide collective goods to their constituencies, either through budgetary allocations ('pork') or legislative amendments. Naturally, it may be somewhat fanciful to try and apply the US models of 'home-style' politics to post-communist countries. Moreover, as will be discussed in the final section, this particular phenomenon of district representation is closely linked to the type of electoral system and the specific use of plurality voting. Nonetheless, as presumably rational actors, Central and Eastern European MPs map also be expected to care for certain kinds of regional or district interests.

Indeed, as the results indicate, Baltic MPs are by no means indifferent to their constituencies and their well-being. A solid majority felt that benefiting their constituency is part of their job. At the same time, when it comes to actually acting upon such duties, most deputies admit that they are able to deal with such things only occasionally or rarely. A comparison of the Baltic states in this regard shows that it is now the Latvian MPs who lead the pack, with a considerably higher sense of responsibility to get pork for their districts. Their mean score of 1.7 in Table 13 repre-

Table 13. 'During the annual debate over the state budget (or supplementary state budgets), how much do you feel it is your responsibility to try and get aid and/or government projects allocated that specifically benefit your district?' Mean, (SD)

\begin{tabular}{cccc}
\hline Estonia & Latvia & Lithuania & Baltic average \\
\hline 2.34 & 1.70 & 2.29 & 2.13 \\
$(0.57)$ & $(0.60)$ & $(0.59)$ & $(0.65)$ \\
\hline
\end{tabular}

$1=$ Very often, $4=$ Never. 
Table 14. 'During the process of adopting the state budget (or a supplementary state budget), how often do you attempt to influence the process in order to provide projects or money for your district?' Mean, (SD)

\begin{tabular}{cccc}
\hline Estonia & Latvia & Lithuania & Baltic average \\
\hline 2.83 & 2.67 & 3.17 & 2.92 \\
$(0.76)$ & $(0.72)$ & $(0.73)$ & $(0.76)$ \\
\hline
\end{tabular}

$1=$ Very often, $4=$ Never.

Table 15. 'During an average parliamentary session, how often do you seek to alter other legislative acts in order to benefit your district?' Mean, (SD)

\begin{tabular}{cccc}
\hline Estonia & Latvia & Lithuania & Baltic average \\
\hline 3.13 & 3.06 & 3.48 & 3.25 \\
$(0.68)$ & $(0.63)$ & $(0.61)$ & $(0.68)$ \\
\hline
\end{tabular}

$1=$ Very often, $4=$ Never.

Table 16. 'How many times per month do you go back to your district?' (\%)

\begin{tabular}{lllcc}
\hline & Estonia & Latvia & Lithuania & Baltic average \\
\hline a) $1-3$ times & 23.2 & 35.2 & 63.8 & 43.2 \\
b) $4-6$ times & 31.9 & 40.8 & 24.5 & 31.6 \\
c) $7+$ & 44.9 & 23.9 & 11.7 & 25.2 \\
\hline
\end{tabular}

Table 17. 'How do you keep in touch with your constituency?

(Please tick all appropriate responses.)' (\%)

\begin{tabular}{lccc}
\hline & Estonia & Latvia & Lithuania \\
\hline a) I hold regular constituency meetings. & 21.0 & 64.8 & 61.1 \\
$\begin{array}{l}\text { b) I use my party's legislative staffers } \\
\text { to respond to constituent problems. }\end{array}$ & 42.3 & 63.4 & 63.7 \\
c) I attend local events (fairs, gatherings, concerts). & 80.3 & 70.4 & 62.8 \\
d) I write articles in the local newspaper. & 54.9 & 71.8 & 46.9 \\
e) I appear on local TV and radio. & 33.8 & 70.4 & 37.2 \\
f) I have too little time to maintain contact & & & \\
with my constituency. & 5.6 & 0.0 & 3.5 \\
\hline
\end{tabular}


sents a significant number of deputies (36.6\%) who felt that such behaviour was a 'very important' responsibility of theirs. Similarly, Latvian concern for district interests is reflected in the significant number of trips deputies make back to the district (see Table 16). Latvian MPs also professed a broader range of ways in which they maintain public contact with their district (see Table 17). Not a single Latvian deputy in the survey claimed that they had too little time to keep in touch with their district.

\section{Interest group politics}

As already noted in the discussion of party activities and the ranking of electoral candidates, the direct influence of interest groups appears to be small in Baltic politics. Naturally, this does not mean that particularistic interests do not find their way into political processes or that their influence is not felt in other ways. Moreover, it would be naïve to think that an MP survey such as this could reveal reliably or openly the extent of such influence. The following assessment of the survey questions that dealt with these issues should therefore be taken with a grain of salt - especially as it pertains to the absolute level of interest influences. In the survey Baltic MPs generally responded that during an average legislative period they only 'occasionally' or even 'rarely' help businesses, interest groups or campaign sponsors in various of governmental affairs (Table 18).

While this correlates with the responses to the question in Table 2 about the amount of time MPs spend meeting with interest groups, it raises questions about how policy is then really made. Are Baltic parliaments procedurally more regulated so that interest groups are only able to meaningfully influence policy decisions through the executive branch or at the level of parliamentary committee chairs (who decide the passage of bills)? Obviously a great deal of policy is decided at the level of decrees and regulations prepared by ministerial officials. However, in each of the Baltic states deputies also have the right to submit private members' bills and amendments, which should provide some inroads for interest groups to influence legislation.

Another indication of how limited the scope of interest group influence on Baltic MPs may be is given in Table 19. When asked to cite some of the ways in which they have helped interest groups, deputies did not appear to give preference to any particular form, whether it was contacting a ministerial official or taking direct legislative action. Again it is possible that interest groups themselves have not yet had extensive access to average deputies. However, anecdotal evidence suggests that amendments and ministerial contacts may be more prevalent. ${ }^{17}$

17 For example, in February 2002, Estonia's Minister for Social Affairs, Siiri Oviir, came under heavy media scrutiny when it turned out that a series of legislative amendments that she had previously sponsored as a private MP coincided word-for-word with a draft proposed by an interest group representing the pharmaceutical industry. Oviir claimed initially that the 
Table 18. 'During an average legislative period, how often do you help businesses, interest groups or campaign sponsors in a variety of governmental matters?' Mean, (SD)

\begin{tabular}{cccc}
\hline Estonia & Latvia & Lithuania & Baltic average \\
\hline 2.99 & 2.76 & 2.75 & 2.92 \\
$(0.27)$ & $(0.71)$ & $(0.79)$ & $(0.67)$ \\
\hline
\end{tabular}

Table 19. 'How often do you help such groups in the following ways?' Mean, (SD)

\begin{tabular}{lcccc}
\hline & Estonia & Latvia & Lithuania & Baltic average \\
\hline $\begin{array}{l}\text { a) I sponsor an amendment } \\
\text { to the national budget. }\end{array}$ & 3.20 & 3.01 & 3.11 & 3.12 \\
& $(0.70)$ & $(0.68)$ & $(0.72)$ & $(0.70)$ \\
$\begin{array}{l}\text { b) I sponsor an amendment } \\
\text { to an existing law. }\end{array}$ & 3.01 & 2.76 & 2.87 & 2.88 \\
$\begin{array}{l}\text { c) I submit a request for information } \\
\text { to a minister during Question Time. }\end{array}$ & $(0.58)$ & $(0.78)$ & $(0.74)$ & $(0.72)$ \\
& $(0.56)$ & $(0.86)$ & $(0.79)$ & $(0.75)$ \\
$\begin{array}{l}\text { d) I contact a minister or a ministerial } \\
\text { official personally on behalf } \\
\text { of the group or its problem. }\end{array}$ & 2.66 & 2.68 & 2.55 & 2.62 \\
$\begin{array}{l}\text { e) I speak to other parliamentary } \\
\text { colleagues on behalf of the groups } \\
\text { or its problem. }\end{array}$ & $(0.56)$ & $(0.69)$ & $(0.77)$ & $(0.69)$ \\
& $(0.55)$ & $(0.74)$ & $(0.75)$ & $(0.70)$ \\
\hline
\end{tabular}

$1=$ Very often, 4 = Never.

text was a coincidence, but the incident showed that interest group politics may flow precisely through such channels. Indeed, the incident also says something about MPs: they may be incapable or may have insufficient time to formulate such amendments themselves, and therefore ask interest groups to prepare 'drafts', which are then put into use without much examination. 


\section{General analysis}

A number of hypotheses and questions arise when the data are analysed through the prism of institutional and electoral theory. Given the fact that the three Baltic electoral systems are so different, one is tempted to ask to what extent cross-country variations in the survey can be explained through institutional variables? In this concluding discussion, the presumable consequences for MP behaviour based on each of the electoral systems in the Baltic states will be posited and then compared with the actual data presented above.

Of the three Baltic countries, Lithuania has the most voter-centred electoral system, with 71 of the 141 members of the Seimas elected in single-member districts that have a first-past-the-post balloting system. This means that at least half of Lithuania's MPs exhibit at least some of the district-centred behavioural tendencies typical of the US Congress or the UK House of Commons - for example, caring more actively for voter and district needs, developing more independent relations from their parties. Indeed, in some respects, the survey's sample size is even larger, as the vast majority of Lithuanian deputies run in both an SMD and an MMD. This means that even if in the previous election an MP was elected from the countrywide MMD, he/she may still maintain close ties with a single-mandate district in the hopes of retaining a mandate at the next election via an SMD victory. Nevertheless, it is clear that only directly elected SMD deputies have an official status in relation to their local constituencies, which MMD deputies can only imitate.

In the survey the sample was slightly skewed in favour of MMD deputies (58) over SMD deputies (46). The range nonetheless allows us to make some correlative analyses. To reiterate the point that was raised in the introduction to this article, the SMD-MMD institutional distinction in Lithuania was not evident with regard to all the variables where it may have been expected. For example, no statistically significant correlation could be discovered between district type and the 'sense of responsibility to get pork for one's district'. Similarly there appears to be no relationship between district type and the four general statements on voter versus national interest, which were presented in Table 12. Lithuanian deputies were the least frequent visitors to their electoral districts (Table 16). Still, robust coefficients of 0.352 and 0.365 existed between the electoral district and how much time a deputy spent at local meetings and on voter problems, respectively. In addition, SMD deputies are more likely (by a coefficient of 0.310 ) to agree that 'providing voter assistance improves electoral chances' or that 'providing voter assistance improves independence in parliament' (0.259). SMD deputies also appear to receive many more voter requests; thus it would seem that Lithuanian voters are also learning to distinguish who is worth talking to with regard to political issues.

Voter care would seem to be a likely preoccupation also for Estonian MPs, since based on Estonian electoral law they too run in fairly small districts, of which there are relatively many (11 or 12 , depending on the year). Indeed, this could be one interpretation for why the Estonian MPs we interviewed tended to visit their dis- 
tricts more than their Latvian or Lithuanian counterparts. Yet in our survey these visits seemed to consist mostly of attending local events (Table 17), and less so constituency meetings or using staffers to respond to voter needs. With regard to the latter issue, it is true that Estonian MPs also have fewer staff resources as allocated by parliamentary rules. However, a second institutional factor deterring constituency ties comes into play through the electoral system: because Estonian MPs can also be elected off of a national list (if they fail to gain the minimum amount of votes in their district in order to be elected directly), they may frequently be more beholden to the party than to their voters during their subsequent parliamentary term. In addition, previous research has shown that of those candidates eventually elected off of a national list, a disproportionate share ran their original campaigns in the main cities of Tallinn and Tartu. Thus rural representation is diminished ${ }^{18}$ [Pettai and Kreuzer 2001]. Also, Estonian voters seem to be equally complacent, as, given the fact that about half of the seats during each election are allocated at the national level, most voters cannot clearly point to any MP as being their district representative. This phenomenon is reflected in the low number of voter requests that the survey indicated Estonian deputies receive. Finally, Estonian MPs in general showed a less particularistic and more 'nationally-oriented' attitude in relation to the four statements on voter versus national interest in Table 12.

Latvian MPs stood out in the survey for their greater-than-expected attention to district 'pork' and interest group politics. This is counterintuitive since the Latvian electoral system (based on party-lists and five large electoral districts) should make Latvian MPs more dependent on their party and should therefore detract from overly particularistic behaviour. Certainly the fact that electoral candidates have to fight for citizens' preference votes in order to be actually elected may increase their incentive to pay attention to constituent affairs. By the same token, because Latvian electoral candidates are allowed to run in more than one district at once (i.e. they may simultaneously be on their party's list in several districts), and most top politicians follow this practice, they may never be sure about which district they may end up being elected from, and therefore, as MPs, they may also not have a clear connection to their ultimate 'electoral district'. If a candidate is originally from one part of Latvia, but ends up being elected from another district (because of the vagaries of party-list totals or individual preference votes), he/she may not even be in a position to actually serve the interests of that district.

The Latvian case could draw our attention to the procedural rules that relate to making budgetary and legislative amendments. For example, it may be that it is easier for Latvian MPs to submit such bills in parliament, and that is why they report engaging in this activity more. At the same time, the parliamentary rules in the

\footnotetext{
${ }_{18}$ Moreover, looking at a cross-tabulation of the geographic type of district (rural vs. urban) and the number of times an MP returns home to his/her district, urban-district MPs were much more likely to have returned home $7+$ times. This means that in the case of MPs who considered their district the capital, 'returning home' was no problem whatsoever. In other words, the data regarding district visitations are skewed by these capital-based deputies.
} 
Baltic states actually give the best hand to Estonian deputies, who are able to submit bills and amendments on their own and without to have more than one sponsor. In Latvia, by contrast, bills need to be sponsored by a minimum of five deputies. This variable therefore remains a puzzle.

\section{Conclusion}

In legislative studies, there are a number of competing conceptual frameworks that are used to make sense of parliamentary behaviour. In the context of consolidating democracies, it is clear that factors related to historical legacies or inherited political culture may have a lot to do with how parliamentarians act. For example, faced with the task of strengthening embryonic democratic institutions, politicians may commit themselves to more collective, national interests, rather than behaving in opportunistic, self-interested ways, even if the institutions otherwise enable such behaviour. Similarly, politicians may only slowly come to understand the incentives embedded in the institutions or rules that they have chosen for their system, for there is clearly a process of learning that goes on no matter how much politicians may think they know what to expect from the rules they put in place. Indeed, at the very least there will always be MPs who were not professional politicians when they entered politics. These people may arrive with entirely different perceptions of life, of society and of politics itself. So at least for an initial period of learning these deputies will exhibit different types of behaviour than those who could more readily be classified as professional politicians.

All of these more distal variables (however difficult they may be to delineate) require us therefore to take with some caution the effects that more proximate institutional variables might have on MP behaviour. The objective of this article was to test (at least in a provisional manner) some of the hypotheses that institutionalelectoral theory provides us with on how MPs should behave based on certain types of institutional-electoral rules. The results are somewhat inconclusive. Some of the starkest differences between the three Baltic states in terms of electoral institutions (e.g. Latvia's simple PR system versus Lithuania's mixed system) do pan out with respect to certain aspects of parliamentarians' self-reported behaviour and attitudes. Others, however, do not. Returning to the argument about political learning, it is possible that over time these remaining hypotheses may also be corroborated as deputies simply learn what 'rational behaviour' means for them under the particular rules they work in. For that kind of definitive test, however, a data time-series would be necessary. Consequently, the examination and explanation of different patterns of parliamentarian behaviour in Central and Eastern Europe as yet remains an emerging research area. 
Vello PETTAI is a professor of comparative politics at the Department of Political Science at the University of Tartu. His current research interests include the institutionalisation of post-communist political elites, party politics and political culture. He has published in World Politics, Studies in Comparative International Development, Nations and Nationalism and East European Politics and Societies.

\section{References}

Agh, Attila and Sandor Kurtan. (eds.) 1995. Democratization and Europeanization in Hungary: The First Parliament, 1990-1994. Budapest: Hungarian Center for Democracy Studies.

Best, Heinrich and Maurizio Cotta. (eds.) 2000. Parliamentary Representatives in Europe, 1848-2000: Legislative Recruitment and Careers in Eleven European Countries. Oxford: Oxford University Press.

Bowler, Shaun, David M. Farrel and Richard S. Katz. 1999. Party Discipline and Parliamentary Government. Columbus: Ohio State University Press.

Cain, Bruce, John Ferejohn and Morris Fiorina. 1987. The Personal Vote: Constituency Service and Electoral Independence. Cambridge: Harvard University Press.

Cox, Gary. 1997. Making Votes Count. Strategic Coordination in the World's Electoral Systems. Cambridge, Cambridge University Press.

Higley, John and György Lengyel. (eds.) 2000. Elites after State Socialism: Theories and Analysis. Lanham, Md.: Rowman and Littlefield Publishers.

Higley, John, Jan Pakulski, and Wlodzimierz Weselowski. (eds.) 1998. Postcommunist Elites and Democracy in Eastern Europe. London: Macmillan.

Frentzel-Zagórska, Janina and Jacek Wasilewski. (eds.) 2000. The Second Generation of Democratic Elites in Central and Eastern Europe. Warsaw: Institute of Political Studies, Polish Academy of Sciences.

Grofman, Bernard and Arend Lijphart. (eds.) 1986. Electoral Laws and Their Political Consequences. New York: Agathon Press.

Kangur, Riho. 2004. “Kandidaatide selekteerimine Eesti parlamendierakondades 1999-2003." Riigikogu toimetised 10: 105-111.

Katz, Richard S. 1986. A Theory of Parties and Electoral Systems. Baltimore: The Johns Hopkins University Press.

Kreuzer, Marcus and Vello Pettai. 2004. "The Formation of Parties and Party Systems: New Insights from the Post-Communist Democracies." World Politics 56: 608-33.

LeDuc, Lawrence, Richard G. Niemi and Pippa Norris. (eds.) 1996. Comparing Democracies: Elections and Voting in Global Perspective. Thousand Oaks: Sage.

Lijphart, Arend. 1994. Electoral Systems and Party Systems. A Study of Twenty-Seven Democracies, 1945-1990. Oxford, Oxford University Press.

Mikkel, Evald and Vello Pettai. 2004. “The Baltics: Independence with Divergent Electoral Systems." Pp. 332-46 in The Handbook of Electoral System Design, edited by J. M. Colomer. New York: Palgrave Macmillan.

Moser, Robert G. and Ethan Scheiner. 2004. "Mixed Electoral Systems and Electoral System Effects: Controlled Comparison and Cross-National Analysis." Electoral Studies 23: 575-99.

Olson, David M and William E. Crowther. 2002. Committees in Post-Communist Democratic Parliaments: Comparative Institutionalization. Columbus: Ohio State University Press. 
Pettai, Vello. 1999. "The Baltic States: Straddling the Post-Communist Divide."

Pp. 123-154 in Democracy in the New Europe: The Politics of Post-Communism, edited by Julie Smith and Elizabeth Teague. London: Greycoat Press.

Pettai, Vello. 2000. "Parlamendi liikmed poliitilises risttules." (Members of Parliament in the Political Crossfire) Riigikogu toimetised 2: 121-128.

Pettai, Vello and Marcus Kreuzer. 1999. "Party Politics in the Baltic States: Social Bases and Institutional Context." East European Politics and Societies 13: 148-189.

Pettai, Vello and Marcus Kreuzer. 2001. "Institutions and Party Development in the Baltic States." Pp. 107-125 in Party Development and Democratic Change in Post-Communist Europe, edited by Paul G. Lewis. London: Frank Cass.

Pettai, Vello and Marcus Kreuzer, Artis Pabriks, and Darius Zeruolis. 2000. "Party Development in the Baltic States: Organization, Governance, and Electioneering." unpublished manuscript.

Shugart, Matthew Soberg and Matthew P. Wattenberg. (eds.) 2001. Mixed/Member Electoral Systems: The Best of Both Worlds? Oxford: Oxford University Press. 